\title{
Pilot plant fermentation of high test molasses compared with blackstrap molasses using factorial design'
}

\author{
Eduardo Cacho, Nivia F. Murphy and Eleanor Fontanet ${ }^{2}$
}

\begin{abstract}
ASTRACT
A two-level Factorial Design study was done for the purpose of making a direct statistical comparison of the performance of high test molasses (HTM) and blackstrap molasses (BM) as fermentation substrates. The dependen variables under study were alcohol yield and congener formation for 24-hour fermentation. Another purpose was to identify those independent variables (and the interactions of those variables) which have significant effects over the dependent variables under study. The independent variables were fermentation substrate, initial yeast cell count, molasses feed addition time and quantily of molasses feed added. Sixteen pilot plant scale (3785 l) fed batch fermentations were performed. Variables which showed a statistically significant $(p=0.05)$ effect on alcohol yield and congener generation were fermentation substrate and quantity of molasses feed added. A significant effect of fermentation substrate on pH and total acidily was also observed. In general BM fermentations were in a more advanced stage and produced higher fusel content than HTM fermentations at $24 \mathrm{hr}$ of fermentation.
\end{abstract}

\section{INTRODUCTION}

The rum industry of Puerto Rico has consistently accounted for about $10 \%$ of the gross insular income, making it the second source of revenue of the island. Traditionally the Puerto Rican rum industry has used blackstrap molasses (BM), a by-product of the sugar industry, as raw material because of its availability and price. However, since 1970 the local sugar industry has not been able to supply all the BM needed by the rum industry. In 1983 rum producers imported 36,749,724 gal. $(1,390,977 \mathrm{hL})$ of BM, $94 \%$ of the total used. BM is imported from other countries, some of which are at present inereasing their rum production to take advantage of the recently relaxed U. S. tariff barriers. This situation has caused great concern among Puerto Rican rum producers.

'Manuscript submitted to Editorial Board 20 August 1986.

${ }^{2}$ Chemical engineer, bacteriologist, Rum Pilot Plant, and assistant statistician, Statistics Section, Agricultural Experiment Station, Mayaguiez Campus, University of Puerto Rico, Rio Piedras, P. R. The authors express their deepest appreciation to Mr. Amador Belardo, Technical Director, Rum Pilot Plant, Agricultural Experiment Station, University of Puerto Rico, for invaluable advice, and to Dr. Guillermo Martínez, Zulma de Ayala, Marta Rivera and Luis Gareia of the Chemistry Section of the Rum Pilot Plant for their fine help in the analytical work required in these studies. 
The Rum Pilot Plant has been working since 1979 on possible alternatives to BM as raw material which could be produced locally to eliminate dependency on outside sources. Emphasis has been placed on methods for the production and evaluation of high test molasses (HTM). HTM is defined as a clarified sugarcane syrup, partially inverted to avoid crystalization, and evaporated to ca. $85^{\circ}$ Brix. A procedure for manufacturing HTM was developed at the Rum Pilot Plant (15), and over the past 5 years comparative studies of HTM and BM have concentrated on nutrients, rate of fermentation, congener generation, characterization of slops and aging of distillates $(8,10,13,18)$. These studies have demonstrated that there are significant differences between HTM and BM in many aspects of rum manufacture.

For this study a set of experiments was designed that allowed direct statistical comparison of the performance of HTM and BM as fermentation substrates on a pilot plant scale while concurrently screening for the effects and the interactions of other independent variables studied. The dependent variables under study were alcohol yield and congener generation. Obviously, the industry would benefit from faster, more efficient fermentation but in terms of an economic analysis the quality of the product also has to be taken into account. Puerto Rican light rums have traditionally been characterized by lower fusel content (propyl, isopropyl, n-butyl, isobutyl, amyl, isoamyl, d-amyl, and other high boilers) than that of heavy type rums, brandies and whiskeys (2). Hence, according to Brau, decreasing the amount of fusel oil produced during the fermentation of process to a minimum would be most desirable (3). Brau (4)

TABLE 1.-Factorial design experimental runs

\begin{tabular}{|c|c|c|c|c|}
\hline \multirow{2}{*}{ Runs } & $x_{1}$ & $\mathrm{X}_{2}$ & $x_{3}$ & $\bar{x}_{4}$ \\
\hline & Raw material & Cell count & Addition time & Gallons added \\
\hline F.D. 1 & HTM & High & High & High \\
\hline F.D. 2 & HTM & High & High & Low \\
\hline F.D. 3 & HTM & High & Low & High \\
\hline F.D. 4 & HTM & High & Low & Low \\
\hline F.D. 5 & HTM & Low & High & High \\
\hline F.D. 6 & HTM & Low & High & Low \\
\hline F.D. 7 & HTM & Low & Low & High \\
\hline F.D. 8 & HTM & Low & Low & Low \\
\hline F.D. 9 & $B M$ & High & High & High \\
\hline F.D. 10 & BM & High & High & Low \\
\hline F.D. 11 & $B M$ & High & Low & High \\
\hline F.D. 12 & $\mathrm{BM}$ & High & Low & Low \\
\hline F.D. 13 & $B M$ & Low & High & High \\
\hline F.D. 14 & $\mathrm{BM}$ & Low & High & Low \\
\hline F.D. 15 & BM & Low & Low & High \\
\hline F.D. 16 & BM & Low & Low & Low \\
\hline
\end{tabular}


also pointed to the importance of the recovery of desirable congeneric substances, such as esters and acids. Martínez (8) in his laboratory scale studies found that HTM resulted in products higher in esters and lower in fusel. We desired to determine whether these favorable results could be replicated on a pilot plant scale.

\section{MATERIALS AND METHODS}

Experimental design

A two-level factorial design consists of high and low levels of each independent variable in all combinations (table 1). For $\mathrm{N}$ variables this results in $2^{N}$ runs. For each variable a measure of the error variance and effect variance is made. If there is no real effect and the calculated variance is merely a measure of error, large differences (as determined by $F$-distribution) between the effect variance and the error variance are improbable (6). We assigned the run order randomly to assure the validity of the results and performed a run test (17) to corroborate that the order was indeed random (table 2).

The two-level factorial design was used to study the effects of the independent variables (raw materials (HTM \& BM), initial yeast cell count, molasses feed addition time, and quantity of molasses feed added) on the dependent variables of interest (alcohol yield, residual sugars as invert, $\mathrm{pH}$, total acidity as acetic, and other congeners generated) all of these at 24-hour fermentation time.

TABLE 2-Run-test-Test for randomness of runs as performed

\begin{tabular}{cccccc}
\hline Runs as performed & $\mathrm{X}_{1}$ & $\mathrm{X}_{2}$ & $\mathrm{X}_{3}$ & $\mathrm{X}_{4}$ & $\begin{array}{c}\text { Runs as per factorial } \\
\text { design }\end{array}$ \\
\hline A & +1 & - & F.D. 4 & & \\
B & - & + & + & + & F.D. 9 \\
C & + & - & + & + & F.D. 5 \\
D & - & + & - & + & F.D. 11 \\
E & - & - & + & - & F.D. 14 \\
F & - & - & + & + & F.D. 13 \\
G & - & - & - & + & F.D. 15 \\
H & + & - & - & - & F.D. 8 \\
I & + & + & + & + & F.D. 1 \\
J & + & + & + & - & F.D. 2 \\
K & - & + & - & - & F.D. 12 \\
L & - & + & + & - & F.D. 10 \\
M & + & - & - & + & F.D. 7 \\
N & + & + & - & + & F.D. 3 \\
D & - & - & - & - & F.D. 16 \\
P & + & - & + & - & F.D. 6 \\
Runs (r) & 9 & 8 & 10 & 9 & \\
\hline
\end{tabular}

$1+$ indicates high level of the variab le and - indicates low level of the variable. 


$$
\begin{aligned}
& \text { Factorial design - variables and levels } \\
& \mathrm{X}_{1}=\text { Raw material } \\
& \text { Levels } \\
& \text { High }=\text { High test molasses (HTM) } \\
& \text { Low }=\text { Blackstrap molasses }(\mathrm{BM}) \\
& \mathrm{X}_{2}=\text { Initial yeast cell count } \\
& \text { Levels } \\
& \text { High }=200 \text { gallons }(757 \mathrm{~L}) \text { with } 270 \times 10^{6} \mathrm{cell} / \mathrm{ml} \text { of Sac- } \\
& \text { charomyces cerevisiae yeast strain PPR-80 } \\
& \text { Low }=100 \text { gallons }(379 \mathrm{~L}) \text { with } 270 \times 10^{6} \mathrm{cell} / \mathrm{ml} \text { of Sac- } \\
& \text { charomyces cerevisiae yeast strain PPR-80 } \\
& \mathrm{X}_{3}=\text { Molasses feed addition time } \\
& \text { Levels } \\
& \text { High }=\text { total quantity added in } 12 \text { hours at constant rate } \\
& \text { Low }=\text { total quantity added in } 16 \text { hours at constant rate } \\
& \mathrm{X}_{4}=\text { Quantity of molasses feed added } \\
& \text { Levels } \\
& \text { High }=290 \text { gallons }(1097 \mathrm{~L}) \text { of approximately } 50 \mathrm{~g} / 100 \mathrm{ml} \text { total } \\
& \text { sugars as invert; theoretically should yield } 10 \% \mathrm{v} / \mathrm{v} \text { al- } \\
& \text { coholic solution } \\
& \text { Low }=230 \text { gallons }(871 \mathrm{~L} \text { ) of approximately } 50 \mathrm{~g} / 100 \mathrm{ml} \text { total } \\
& \text { sugars as invert; theoretically should yield } 8 \% \mathrm{v} / \mathrm{v} \text { al- } \\
& \text { coholic solution. }
\end{aligned}
$$

\section{Equipment}

Fermentations were carried out in $3785 \mathrm{~L}$ (working capacity) tanks with covered tops to achieve anaerobic conditions. These tanks were equipped with a 2-inch diameter outlet for the $\mathrm{CO}_{2}$ generated, a $65 \mathrm{ft}^{2}$ surface area coil for cooling water, a sight gage for measuring liquid level, a thermometer, and 1.5-hp centrifugal pump for recirculating the fermenting broth. We added the molasses feed at a constant rate by pumping from a $1900 \mathrm{~L}$ (working eapacity) tank with sanitary metering pump equipped with a $3 / 4 \mathrm{hp}$ variable speed drive. Flow rate was adjusted manually and measured with a rotameter. The molasses mash and fermented broth were centrifuged with a Westfalia Separator Model NA7-06-076. ${ }^{3}$ Distillation was performed with the Rum Pilot Plant Beer Column. Aside from the distillation column all other materials of construction in direct contact with the molasses feed or broth were of type 316 stainless steel.

\footnotetext{
${ }^{3}$ Trade names in this publication are used only to provide specific information. Mertion of a trade name does not constitute a warranty of equipment of malerials by the Agricultural Experiment Station of the University of Puerto Rico, nor is this mention a statement of preference over other equipment or materials.
} 
Experimental procedures

Initially all the equipment was sterilized with live steam. The fermentation feed consisted of a $50 \mathrm{~g} / 100 \mathrm{ml}$ fermentable sugar solution (with HTM or BM accordingly). Ammonium sulfate, $1.5 \mathrm{~g} / \mathrm{L}$ for BM and $2 \mathrm{~g} / \mathrm{L}$ for HTM, was added as nitrogen source; $\mathrm{pH}$ was adjusted with sulfuric acid to 4.7.' The molasses feed was pasteurized at $77^{\circ} \mathrm{C}$ for $45 \mathrm{~min}$ and then cooled to $30^{\circ} \mathrm{C}$ with cooling water through the internal coil heat exchanger. The feed was then centrifuged and ready for use in the fermentation. We prepared the yeast inoculum by scaling up the procedures used in the laboratory scale studies (10). Yeast cell count was determined on a Newbauer Hemacytometer.

The fermentor was first charged with the amount of tap water required for each experiment; subsequently, the yeast inoculum was added, followed by the molasses feed, which was added at a constant rate. The final volume for all the runs was $3785 \mathrm{~L}$.

All the experiments ran for 24 hours starting from the molasses feed addition. Throughout the experiment the recireulating pump was running and the temperature in the fermenter was kept at $86 \pm 2^{\circ} \mathrm{F}\left(30^{\circ} \mathrm{C}\right)$ with cooling water through the inner coil.

To monitor the process, we drew samples every 4 hours and analyzed them for total sugars as invert $(\mathrm{g} / 100 \mathrm{ml}), \%$ alcohol $(\mathrm{v} / \mathrm{v})$, total acidity $(\mathrm{g} / \mathrm{L})$, and $\mathrm{pH}$ as described in the Official Analytical Methods of the Rum Pilot Plant (12). In addition, the 24-hour samples were analyzed for other congeners by gas chromatography (8). To stop the fermentation, we added $2 \mathrm{~g} / \mathrm{L}$ of mercuric chloride to the samples. At the end of 24 hours the fermentation broth was centrifuged and then distilled. In order to keep interfering variables to a minimum, we based the statistical studies on the 24-hour sample before centrifugation and distillation.

\section{Statistical analysis}

The data for the 24-hour sample were analyzed with a System 34 IBM computer. Since no replications were done, the error estimate used higher order interactions to estimate experimental error as follows (5): the four three-factor interactions and the four-factor interaction were pooled to estimate the experimental error.

\section{RESULTS AND DISCUSSION}

By means of the Run-test it was determined there was randomness of assignment in terms of high and low treatments for each of the variables, as shown in table 2 . The critical values of $(x)$ show that we should accept the null hypothesis of randomness $(p=.05)$ if $4<\mathrm{r}<14$. Therefore, the null hypothesis of randomness cannot be rejected.

`Optimum, as reported by Murphy (10). 
TABLE 3. Characterization of 24 -hour fermented broth

\begin{tabular}{|c|c|c|c|c|c|c|c|c|c|c|c|c|c|c|c|}
\hline \multirow[b]{2}{*}{ Run } & \multirow{2}{*}{$\begin{array}{c}\% \text { of } \\
\text { theore- } \\
\text { tical yield }\end{array}$} & \multirow[b]{2}{*}{$\mathrm{pH}$} & \multirow[b]{2}{*}{$\begin{array}{c}\text { Acidity } \\
\mathrm{g} / \mathrm{1}\end{array}$} & \multirow[b]{2}{*}{$\begin{array}{l}\text { Alcohol } \\
\%(v / v)\end{array}$} & \multirow{2}{*}{$\begin{array}{c}\text { Total } \\
\text { sugar } \\
\text { as invert } \\
\text { g/100 mi } \\
\end{array}$} & \multicolumn{10}{|c|}{ Congeners $\mathrm{mg} / 100 \mathrm{ml}$ at $80^{\circ} \mathrm{P}$} \\
\hline & & & & & & $\begin{array}{l}\text { Acetal- } \\
\text { dehyde }\end{array}$ & $\begin{array}{l}\text { Methyl } \\
\text { acetate }\end{array}$ & $\begin{array}{l}\text { Ethyl } \\
\text { acetate }\end{array}$ & Acetal & $\begin{array}{l}\text { Propyl } \\
\text { alcohol }\end{array}$ & $\begin{array}{l}\text { Isobuty] } \\
\text { alcohol }\end{array}$ & $\begin{array}{l}\text { Isoamyl } \\
\text { acetate }\end{array}$ & $\begin{array}{l}\eta \text {-Butyl } \\
\text { alcohol }\end{array}$ & $\begin{array}{l}\text { Isoamyl } \\
\text { alcohol }\end{array}$ & $\begin{array}{l}\text { Amyl } \\
\text { alcohol }\end{array}$ \\
\hline F.D. $1^{1}$ & 71.96 & 3.67 & 4.93 & 8.7 & 4.33 & 15.4 & 10.6 & 5.8 & 0 & 32.5 & 10.8 & 2.9 & 1.2 & 27.0 & 0.4 \\
\hline F.D. 2 & 80.48 & 3.59 & 4.86 & 7.8 & 2.26 & 10.6 & 9.6 & 6.5 & 0 & 25.8 & 8.1 & 4.5 & 2.5 & 28.8 & 0.5 \\
\hline F.D. 3 & 71.64 & 3.57 & 4.94 & 8.5 & 4.11 & 10.8 & 5.6 & 0 & 2.3 & 23.0 & 8.4 & 0 & 6.5 & 16.0 & 0 \\
\hline F.D. 4 & 90.84 & 3.61 & 4.36 & 7.8 & 1.12 & $14.9^{8}$ & $8.4^{*}$ & $4.9^{8}$ & $1.0^{3}$ & $23.5^{3}$ & $9.2^{3}$ & $1.5^{3}$ & $3.5^{3}$ & $24.8^{3}$ & $0.3^{3}$ \\
\hline F.D. 5 & 75.00 & 3.86 & 4.73 & 7.3 & 4.65 & 18.6 & 5.5 & 7.7 & 0 & 26.3 & 4.9 & 1.1 & 6.0 & 24.1 & $0 . \overline{5}$ \\
\hline F.D. 6 & 72.65 & 3.80 & 4.04 & 6.1 & 2.90 & 12.2 & 5.1 & 2.5 & 0 & 14.8 & 7.7 & 0 & 0.6 & 23.2 & 0 \\
\hline F.D. 7 & 72.45 & 3.51 & 4.64 & 7.1 & 4.77 & 8.8 & 8.6 & 0 & 4.6 & 15.0 & 11.4 & 0 & 6 & 22.8 & 0 \\
\hline F,D 8 & 88.47 & 3.61 & 4.48 & 6.8 & 1.95 & 28.1 & 13.5 & 11.8 & 0 & 27.0 & 12.9 & 2.2 & 1.6 & 31.5. & 0.5 \\
\hline F.D. $q^{2}$ & 92.63 & 4.35 & 7.04 & 10.6 & 1.35 & 45 & 4.5 & 3.4 & 0 & 22.9 & 15.6 & 0 & 1.1 & 48.4 & 0.8 \\
\hline F.D. 10 & 89.03 & 4.16 & 5.88 & 8.2 & 1.01 & 1.8 & 4.8 & 0 & 0 & 29.2 & 13.6 & 0 & 0 & 40 & 0 \\
\hline F.D. 11 & 98.13 & 4.13 & 7.08 & 9.7 & 1.28 & 4.9 & 2.9 & 3.7 & 0 & 22.3 & 12.4 & 0.4 & 3.3 & 44.5 & 0.4 \\
\hline F.D. 12 & 93.01 & 4.11 & 4.84 & 8.1 & 1.20 & 5.9 & 3.9 & 0 & 0 & 23.7 & 14.8 & 0 & 0 & 40.4 & 0 \\
\hline F.D. 13 & 94.01 & 4.18 & 6.39 & 8.9 & 2.45 & 9.4 & 11.6 & 11.6 & 0 & 27.5 & 20.2 & 3.4 & 0.4 & 57.6 & 1.2 \\
\hline F.D. 14 & 96.11 & 4.19 & 5.56 & 8.2 & 1.10 & 4.9 & 2.9 & 2.9 & 0 & 19.0 & 15.1 & 0 & 1.0 & 45.4 & 0.5 \\
\hline F.D. 15 & 90.81 & 4.37 & 5.98 & 8.7 & 2.80 & 7.5 & 10.2 & 6.6 & 0 & 21.7 & 24.8 & 2.6 & 1.3 & 80.8 & 1.3 \\
\hline F.D. 16 & 94.71 & 4.53 & 5.80 & 7.5 & 1.05 & 9.3 & 6.5 & 0 & 0 & 19.7 & 16.9 & 0 & 0 & 37.8 & 16.4 \\
\hline \multicolumn{16}{|c|}{ Averages and standard deviation } \\
\hline $\begin{array}{l}\text { F.D. I to } \\
\text { F.D. } 8 \\
\text { (HTM) }\end{array}$ & $\begin{array}{c}\tilde{X}=77.94 \\
\sigma=7.80\end{array}$ & $\begin{array}{l}\bar{X}=3.65 \\
\sigma=0.12\end{array}$ & $\begin{array}{l}\bar{X}=4.62 \\
\sigma=.318\end{array}$ & $\begin{array}{l}\bar{X}=7.51 \\
\sigma=.865\end{array}$ & $\begin{array}{l}\bar{X}=3.26 \\
\sigma=1.39\end{array}$ & $\begin{aligned} \tilde{X} & =14.98 \\
\sigma & =6.68\end{aligned}$ & $\begin{array}{l}\bar{X}=8.36 \\
\sigma=3.15\end{array}$ & $\begin{array}{l}\bar{X}=4.9 \\
\sigma=4.33\end{array}$ & $\begin{array}{l}\breve{X}=.99 \\
\sigma=1.81\end{array}$ & $\begin{array}{l}\tilde{X}=23.49 \\
\sigma=6.514\end{array}$ & $\begin{array}{l}x=9.17 \\
\sigma=2.698\end{array}$ & $\begin{array}{l}\vec{x}=1.53 \\
\sigma=1.75\end{array}$ & $\begin{array}{l}\overline{\mathrm{x}}=3.51 \\
\sigma=2.61\end{array}$ & $\begin{aligned} \bar{X} & =24.77 \\
\sigma & =5.00\end{aligned}$ & $\begin{array}{l}\bar{X}=.27 \\
\sigma=.256\end{array}$ \\
\hline$=$ F.D. 1 to & & & & & & & & & & & & & & & \\
\hline $\begin{array}{l}\text { F.D. } 16 \\
\text { (BM) }\end{array}$ & $\begin{aligned} X & =92.93 \\
\sigma & =2.20\end{aligned}$ & $\begin{aligned} \hat{X} & =4.25 \\
\sigma & =.148\end{aligned}$ & $\begin{array}{l}X=6.07 \\
\sigma=.752\end{array}$ & $\begin{aligned} X & =8.75 \\
\sigma & =1.01\end{aligned}$ & $\begin{array}{l}\bar{x}=1.53 \\
\sigma=.692\end{array}$ & $\begin{aligned} X & =7.29 \\
\sigma & =3.01\end{aligned}$ & $\begin{aligned} X & =5.91 \\
\sigma & =3.31\end{aligned}$ & $\begin{array}{l}X=3.53 \\
\sigma=4.01\end{array}$ & $\begin{aligned} X & =0 \\
\sigma & =0\end{aligned}$ & $\begin{array}{l}X=23.25 \\
\sigma=3.541\end{array}$ & $\begin{array}{l}X=16.68 \\
\sigma=4.025\end{array}$ & $\begin{array}{l}X=0.8 \\
\sigma=1.38\end{array}$ & $\begin{array}{l}X=.89 \\
\sigma=1.11\end{array}$ & $\begin{array}{l}X=49.41 \\
\sigma=14.10\end{array}$ & $\begin{array}{l}X=2.58 \\
\sigma=5.61\end{array}$ \\
\hline
\end{tabular}


Table 3 shows the values for the dependent variables under study, alcohol yield and congener generation, other dependent variables that were deemed relevant for the interpretation of the results, and averages and standard deviations for HTM runs and BM runs. Runs F.D. 1 to F.D. 8 include the HTM runs and runs F.D. 9 to F.D. 16 include the BM runs.

For BM runs, alcoholic yield was higher on the average (92.93 vs. $77.94 \%$ for HTM) while the standard deviation values were lower (2.2 vs. 7.80 for HTM). Basically for BM runs the fermentation was elose to completion for all runs, whereas for the HTM runs the fermentation was in different stages of completion at 24 hours. Through statistical analysis (table 4) it was determined that this effect of raw material on yield was significant $(p=0.01)$.

The average resultant $\mathrm{pH}$ was lower for the HTM runs (3.65 vs. 4.25 for BM) even when the average total acidity was lower for HTM runs (4.62 vs. 6.07 for BM). Through statistical analysis it was determined that this effect of raw material on $\mathrm{pH}$ and total acidity was significant $(p=0.01)$. This phenomenon had been observed by Murphy in laboratory scale experiments (9) and could be explained by the lower buffering capacity inherent in the HTM. This lower $\mathrm{pH}$ should be expected to have a detrimental effect on alcohol yield since the optimum $\mathrm{pH}$ for ethanol production is from 4.5 to 5.0 (1).

The tabulation below confirms the previously observed trend of congener formation (8) whereby HTM fermentations generate more esters and less fusel.

\begin{tabular}{lcr} 
& $H T M$ & \multicolumn{1}{c}{$B M$} \\
Acetaldehyde & 14.9 & 7.3 \\
Esters & 14.8 & 10.2 \\
Acetal & 1.0 & 0.0 \\
Fusel & 61.2 & 92.8 \\
Total & 91.9 & 110.3
\end{tabular}

Those congeners that exhibit statistically significant differences dependent on raw material are acetaldehyde, isobutyl alcohol, n-butyl alcohol and isoamyl alcohol. No significant difference was found for esters (table

TABLE 4.-F values for significant effects

\begin{tabular}{|c|c|c|c|c|c|c|c|}
\hline \multirow{2}{*}{$\begin{array}{l}\text { Independent } \\
\text { variables }\end{array}$} & \multicolumn{7}{|c|}{ Dependent variables } \\
\hline & Yield & $\mathrm{pH}$ & Acidity & $\begin{array}{l}\text { Acetal- } \\
\text { dehyde }\end{array}$ & $\begin{array}{l}\text { Isobutyl } \\
\text { alcohol }\end{array}$ & 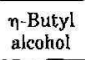 & $\begin{array}{c}\text { Isoamyl } \\
\text { alcohol }\end{array}$ \\
\hline $\mathrm{X}_{\mathrm{I}}$ (raw material) & $51.19^{* * 1}$ & $68.44^{* * *}$ & $44.93^{* *}$ & $8.17^{* 2}$ & $25.92^{* *}$ & $8.63^{*}$ & 26.14 *** \\
\hline $\mathrm{X}_{1}$ (gallons added) & $6.78^{*}$ & & $11.78^{*}$ & & & & \\
\hline
\end{tabular}


4). Acetaldehyde differences can be explained in terms of a deficiency of growth substances (11). n-Butyl alcohol is the only fusel component which is found in signficantly higher concentrations in HTM fermentations (average 3.51 vs. 0.89 for BM). Most of the fusel content in BM fermentations can be accounted for by isoamyl alcohol, which is in a concentration twice as high as in HTM fermentations and accounts for $53.2 \%$ of the fusel in BM fermentations.

Table 4 shows that the independent variables Raw Material $\left(\mathrm{X}_{1}\right)$ and gallons of molasses feed added $\left(\mathrm{X}_{4}\right)$ are responsible for the effects registered. Although the negative effect of using higher levels of sugar concentrations on yield is well documented, it was desired to determine whether there were any interactions with other independent variables; none were observed.

The effect of $\mathrm{X}_{4}$ on acidity can be explained by the amount of sulfuric acid needed to adjust the $\mathrm{pH}$ to 4.7.

Although the HTM fermentations are definitely slower under the conditions studied it is important to remember that BM fermentations have been optimized by many years of experimentation and experience, BM being the traditional raw material for rum manufacture. This study points to the need of future studies to optimize HTM fermentations in terms of rate of fermentation. Specifically, studies on nutrients and $\mathrm{pH}$ levels which have proven important for ather raw materials $(7,14)$ are necessary for HTM. Also, the effect of different levels of invert sugars (50-65\% for HTM; 20\% for BM) could be responsible for different rates of fermentations (16). They should be studied.

\section{RESUMEN}

Comparación de la fermentación a escala piloto de mieles ricas y finales con un diseño factorial

Se llevó a cabo un estudio estadístico tipo diseño factorial a dos niveles para comparar estadísticamente el comportamiento de dos substratos de fermentación: mieles ricas y mieles finales. Además se perseguía identificar las variables independientes ( $y$ las interacciones de esas variables) que tienen efectos significativos sobre las variables dependientes que se mencionan más adelante; rendimiento de alcohol y generación de congenéricos luego de $\mathbf{2 4}$ horas de fermentación. Las variables independientes fueron substrato de fermentación, conteo inicial de levadura, tiempo de adición de miel y cantidad de miel ar̃adida. Para este propósito se efectuaron 16 fermentaciones de tipo semicontinuo a escala de planta piloto (3785 L). Las variables que tuvieron un efecto estadisticamente significativo $(p=0.05)$ sobre el rendimiento alcohb́lico y la generación de congenéricos fueron el substrato de fermentación y la cantidad de miel añadida. También se abservó un efecto significativo del substrato de fermentación sobre el pH y la acidez tofal. En general, las fermentaciones con mieles finales estaban más adelantadas y tenían un contenido de fusel más alto que las fermentaciones con miel rica después de $\mathbf{2 4}$ horas de fermentación. 


\section{LITERATURE CITED}

1. Anonymous, Ethanol fuels reference guide, Solar Energy Research Institute, Golden, Colorado.

2. Batiz, H. et al., 1975. Composición de los rones comerciales de Puerto Rico de 1963 , 1965, 1967, 1969 y 1971, Progr. Rep. 1-75, Rum Pilot Plant, Agric. Exp. Stn. Univ. P. R., Rio Piedras, P. R.

3. Brau, H., 1957. Review on the origin and composition of fusel oil, Technical Paper No. 17, Agric. Exp. Stn. Univ. P. R., Río Piedras, P. R.

4. Brau, H., 1958. Considerations on the convenience of distilling at high proof in continuous alcoholic distillation for beverages, J. Agric. Univ. of P. R, 42 (4): 248-57,

5. Cochran and Cox, 1984. Experimental Designs. 2nd ed, p. 219.

6. Davis, 0. L., Ed, 1954. The Design and Analysis of Industrial Experiments, Hafmer Publishing Company, New York.

7. Jones, R. P., N. Pammet and P. F. Greenfield, 1981. Alcohol fermentation by yeasts the effect of environmental and other variables, Process Biochemistry 16 (3): 42-9.

8. Martinez, G. and N. Murphy, 1984. Congeners from high-test molasses alcoholic fermentation, J. Agric. Univ. P. R. 68 (1): 59-66.

9. Murphy, N. F., 1983. Annual Progress Report of Research Project H-279, Factors affecting the fermentation efficiency of molasses by the yeast and their effect on the quality of rum, Rum Pilot Plant, Agric. Exp. Stn. Univ. P. R., Río Piedras, P. R.

10. Murphy, N., 1984. Fermentation of high-test molasses, J. Agric. Univ. P. R. 68 (1): $33-44$.

11. Nykanen, L. and H. Soumalainen, 1983. Aroma of Beer, Wine and Distilled Alcoholic Beverages. D. Reidel Publishing Company, Dordrecht, Holland, p. 4.

12. Official Analytical Methods of the Rum Pilot Plant, 1969. Agric. Exp. Stn. Univ. P. R., Río Piedras, P. R.

13. Ramírez, M., 1982. Characterization of slops of high test molasses alcoholic fermentation, J. Agric. Univ. P. R. 66 (3): 235-37.

14. Reich, G. T., 1945. Molasses distiller's dried yeast, Sugur 40 (1): 26-9.

15. Rosado, E., 1982. Método para la elaboración de melaza rica, Progress Report No. 23-83, Rum Pilot Plant, Agric. Exp. Stn. Univ. P. R., Río Piedras, P. R.

16. Rose, A. H. and J. S. Harrison, Ed, 1971. The Yeasts, Volume 2, Academic Press, London and New York, pp. 4-5.

17. Siegel, S., 1956. Nonparametric Statistics for the Behavioral Sciences, McGraw-Hill Book Company, New York.

18. Torres, C. S., Z. de Ayala and M. I. Rivera, 1987. Aging of high-test molasses rums. J. Agric. Univ. P. R. 71 (2): 137-5\%. 